\title{
IMPACT OF GROWTH REGULATORS ON IN VITRO GROWTH OF BANANA (MUSA SPP) CULTURED: A REVIEW
}

\author{
Katkam Priyanka \\ Department of Horticulture \\ Lovely Professional University, Phagwara, Punjab
}

Received: 25.05.2020

Revised: 05.06.2020

Accepted: 15.06.2020

\begin{abstract}
Banana is important fruit crop in horticulture where it propagates through suckers which takes immense time for production and with low multiplication rate, to overcome these type of situation some protocols have been made such as the micro propagation where the tissue culture of banana is applied with help of plant growth regulators such as auxins and cytokinins are used at different concentration to attain the definite good results till now many studies had been done in the tissue culture of banana. In the present study it was observed that the explants cultured in MS medium containing $4 \mathrm{mg} / \mathrm{l} \mathrm{BAP}+0.5 \mathrm{mg} / \mathrm{l}$ IAA had highest number of shoot buds and number of shoots. Similar result was studied by Muhammad et al. (2007) where the highest multiplication ratio was observed at $4 \mathrm{mg} / \mathrm{l}$ BAP along with $1 \mathrm{mg} / \mathrm{l}$ IAA. Habiba et al. (2002) and Ahmed et al. (2014) reported that $4 \mathrm{mg} / \mathrm{l} \mathrm{BAP}$ in combination with $2 \mathrm{mg} / \mathrm{l}$ IAA shown remarkable results.
\end{abstract}

\section{Keywords:}

\section{INTRODUCTION}

Banana is considered as staple food of many countries and it is accepted as food, fruit, fodder crop and India is the largest producing country among the world, and through tissue culture we can produce seedless banana at higher rate and also triploids in less time and through the year of any season. The International Musa germplasm collection is sited at the INIBAP (International Network for the Improvement of Banana and Plantain) Transit Centre at K.U.Leuven. The strategy of tissue culture is producing infection free plants stocks and is spread by meristem tip culture. Furthermore, it was found that tissue cultured banana is better in terms of shape, taste, and nutritional value, in addition to obtaining a crop that is free of viral diseases banana plant usually propagated vegetatively through the suckers which grows from lateral buds originating from corms, and suckers are separated for individual plant. Conventional vegetative multiplication of banana has showed negative impacts rather than in vitro cultivation where it is alternative option for more production at less time (Hwang et al., 1984) Tissue culture approaches would also allow for off-season production of fast growing plants compared to conventionally propagated ones (Eckstein and Robinson, 1995).

\section{Culture media}

Till date only MS media is reported to be best medium used in tissue culture of banana because it is supplemented with different macro and micro nutrients and vitamins. the success of the tissue culture depends on the selection of media apart from MS media many other mediums are reported such as the other popular media include B5 (Gamborg et al., 1968), SH (Schenk and Hildebrant, Review of literature 10 1972), N6 (Chu et al., 1975) and LS (Linsmaier and Skoog, 1975, Raghavendar et al ., 2019).

*Corresponding author: priyanka.piya411@gmail.com 
Akbar and Roy (2006) cultured banana explants on MS medium supplemented with $0.5 \mathrm{mg} / \mathrm{l}$ of BA, Kn and NAA and found that addition of $10 \%$ coconut water to the medium resulted in increased number of differentiated shoots per culture. It was also found that acclimatization and transplantation performances of plants was superior for those rooted in liquid medium compared to those rooted in solid medium. It was also reported that MS medium supplemented with sucrose and glucose combination (1:1) at the concentration of $30 \mathrm{gm} / \mathrm{l}$ showed the optimum shoot proliferation Madhulata et al. (2006).

\section{MICROPROPAGATION}

It is the rapid method of duplication of stock plant material to produce many progeny using the tissue culture method in this type plants are produce through the small plant part which is excised from mother plant which is used as explants and it is multiplied and produce true to type plants in less time and infection free plants this technique had been to applied to substantial propagated plant species.

\section{ROLE OF GROWTH REGULATORS IN TISSUE CULTURE}

"Plant growth regulators usually are defined as organic compounds, other than nutrients, that in small concentrations, affect the physiological processes of plants”. In practical purpose, they are defined as either natural or synthetic compounds that are applied directly to plant to alter its life processes Plant growth regulators (PGRs) have been considered as one of the most critical inputs for in vitro culture, as the processes of differentiation, de-differentiation and re-differentiation are greatly dependent on the quality and quantity of these components in the culture media (Youmbi E et al. 2006). Studying on plant growth hormones on different crops varies their concentration and use to particular crop (Shelake RM et al. 2011 ). Especially in crops like banana, wherein a number of genomic groups exist, the PGR requirement may not necessarily be similar for all members of the group Buah JN et al. 2010 ). Thus, screening the efficacy of the PGRs for optimizing their kind and concentrations will be a continuous process as far as the new types with potential for commercialization are identified and added to the global diversity Plant growth regulators are essential in tissue culture as they are responsible for rooting and shooting. these regulators are essential for growth phases of the explants these are cytokinins, auxins, abscisic acid, and gibberellins Auxins and cytokinins, or more specifically, the balance between the two, is important for the organogenesis development in tissue culture plants
These plant growth regulators are added in small concentration to the media they have significance effect on growth and development.

\section{IMPACT OF CYTOKININ ON \\ IN VITRO GROWTH OF BANANA}

This is the important plant growth regulator which initially produce where cell division takes naturally and synthetically BAP are used for the inducing the shoots alongside with auxins. Cytokinins such as benzyl aminopurine (BAP) and kinetin are known to reduce the apical meristem dominance and induce both axiliary and adventitious shoot formation from meristematic explants in banana . However, the application of higher BAP concentrations inhibits elongation of adventitious meristems and the conversion into complete plants $(\mathrm{N}$. Jafari et al, 2011).

The use of cytokinin in plant nutrient media for in-vitro culture depends on plant tissue growth stage and expected end product In studies conducted on banana, apical meristems. cultured in media of high cytokinin concentration or lower cytokinin at the first stage then transferred to a media with higher cytokinin concentration where the increase in concentration especially BA significantly enhanced buds proliferation The effect of nutrient medium constituents on growth and development of banana plantlets produced in vitro was evaluated by Hussein (2012). He found that the medium with sucrose at $30 \%$ supplemented with $0.4 \mathrm{mg} / \mathrm{l} \mathrm{BA}$ was the most optimum for banana shoot tip culture as expressed by better growth vigour, plantlet height, fresh weight as well as stronger shoot and root system Cytokinins such as benzylaminopurine (BAP) and kinetin are generally known to reduce the apical dominance and induce both axillary and adventitious shoot formation from meristamatic explants in banana and the most established banana shoot tip culture system was achieved by using BAP as a supplement to basal media (Jafari et al., 2010). Bhosalo et al. (2011) reports that multiple shoot initiation occurs after 60 days of inoculation in shoot tip culture of banana variety Basari, the frequency of bud formation doubled and the fresh weight increased about four times higher in media with BAP at $3 \mathrm{mg} / \mathrm{l}$ were compared to media supplemented with $7 \mathrm{mg} / \mathrm{l}$ of BAP. BAP strongly stimulates growth of axillary, adventitious and foliar buds (Buah et al., 2010). Yagami banana cultivar and obtained better results with $6.0 \mathrm{mg} \mathrm{L}-1$ of BAP concentration obtaining an average of 9.55 shoots per initial explants Ngomuo et al. (2013). Where as Urazibara et al. (2015) obtained a higher number of shoots (8.8) using the 4 mg L-1 BAP concentration for red banana micropropagation. 


\section{IMPACT OF AUXIN ON IN VITRO GROWTH OF BANANA}

Auxin were first discovered by francis Darwin and his father Charles Darwin. well plants naturally have growth hormones present within them which required for them in growth and development some of are for example Indole butyric acid (IBA) and Indole-3-acetic acid (IAA), well high amount of auxin with compare to cytokinin results in root initiation as early then the shoot initiaton many studies have been done on auxin and cytokinin. NAA is widely used auxin in plant tissue culture for banana well many studies had been showed that balance concentration of BAP and NAA had given good results in rooting and shooting in callus, Bekheet and Saker (1999) reported the superiority of NAA over IAA and IBA in the in vitro rooting of banana plantlets cv. William, Grande Naine and Maghraby where ms media without harmones showed good results (Musa sapientum) Ahsan et al. (1998) Auxins have been reported to shorten the time required for the regeneration of roots as well as increase in the number of roots per culture in Musa shoots (Hiratsuka et aI., 1989)

\section{CONCLUSION}

MS media without growth regulators gave a minimal response and was the least effective. Hundred per cent response was observed in MS+1.0 mgl-1NAA and MS+1.0 mgl-1 NAA+0.2 mgl-1 BAP while the media MS+0.5 mgl1NAA and MS+0.5 mgl-1NAA+0.2 mgl-1BAP gave a good response of $90 \%$ each. The media without any growth regulators gave a response of only $25 \%$ for growth and development (ROBERT LALRINSANGA et al 2013)

\section{REFERENCE}

1. 2013 International Conference on Agriculture and Biotechnology IPCBEE vol. 60 (2013) (C) (2013) IACSIT Press, Singapore DOI: 10.7763/IPCBEE. 2013. V60. 23.

2. Adkins SW, et al. Somaclonal variation in ricedrought tolerance and other agronomic characters. Aust J Bot. 1995;43:201-209.

3. Ahloowalia BS. (1975). Regeneration of ryegrass plants in tissue culture. Crop Sci. 15:449-452.

4. Ahmed, S., Sharma, A., Singh, A.K., Wali, V.K. and Kumari, P. (2014). In vitro multiplication banana (Musa sp.) cv. GRAIN NAINE. African J. Biotechnol., 13(27):2696- 2703.

5. Ahsan Habib, Jahan, M.A.A. and Hossain, M.T. (1998). Acceleration of the process of in vitro root development in Musa sapientum var. Sagar. Bangladesh J. Sci. Ind. Res. 333: 341-344.
6. Akbar, M. A. and Roy, S. K. (2006). Effect of liquid medium on rooting and acclimatization of regenerated micro shoots of banana (Musa sapientum L.) cv. Sagar. Plant Tissue Culture \& Biotechnology, 16: 11-18.

7. Bekheet, S.A. and Saker, M.M. (1999). Rapid mass micropropagation of banana. Bull. Nat. Res. Centre Cairo. 24(2): 221-232.

8. Bhosala, U. P., S. V. Dubhashi, N. S. Mali and H. P. Rathod. (2011). In vitro shoot multiplication in different species of Banana. Asian Journal of Plant Science and Research, 1(3) : 23-27.

9. Brown, D. C. W., Finstad, K. I. and Watson, E. M. (1995). Somatic embryogenesis in herbaceous dicots In: In Vitro Embryogenesis of Plants, 345-416.

10. Buah JN, Danso E, Taah KJ, Abole EA, Bediako EA, Asiedu J, Baidoo R. (2010). The effects of different concentrations of cytokinins on the in vitro multiplication of plantain (Musa sp.). Biotechnology, 9:343-34.

11. Chu, C. C., Wang, C. C., Sun, C. S., Hsu, C., Yin, K. C., Chu, C. Y. and Bi, F. Y. (1975). Establishment of an efficient medium for anther culture of rice through comparative experiments on the nitrogen sources. Scientia Sinica, 18: 659-668.

12. Gamborg, O., Miller, R. and Ojima, K. (1968). Nutrient requirement suspensions cultures of soybean root cells. Experimental Cell Research, 50: 151-158

13. Habiba, U., Reza, S., Saha, M.L., Khan, M.R. and Hadiuzzaman, S. (2002). Endogenous bacterial contamination during in vitro culture of table banana: identification and prevention. Plant Tissue Cult., 12 (2) :117-124.

14. Hussein, N. (2012). Effect of nutrient media constituents on growth and development of banana (Musa spp.) shoot tip cultured in vitro. African Journal of Biotechnology, 11: 9001-9006.

15. Linsmaier, E. M. and Skoog, F. (1975). Organic growth factor requirements of tobacco tissue cultures. Physiologia Plantarum, 18: 100.

16. Madhulatha, P., Kirubakaran, S. I. and Sakthivel, N. (2006). Effects of carbon sources and auxins on in vitro propagation of banana. Biologia Plantarum, 50: 782-784.

17. Muhammad, A., Rashid, H. and Hussain, I. (2007). Proliferationrate effects of BAP and kinetin on banana (Musa spp. Aaa group) 'Basrai'. Hort. Sci., 42(5) : 1253-1255.

18. N. Hussein (2012). "Effects of Nutrient Media Constituents on Growth and Development of Banana 
(Musa spp.) Shoot Tips Cultured in Vitro,”. African Journal of Biotechnology. 11 (37): 9001-9006.

19. N. Jafari, R. Y. Othman and N. Khalid. (2011). "Effect of Benzylaminopurine (BAP) Pulsing on in Vitro Shoot Multiplication of Musa acuminata (Banana) cv. Berangan,. African Journal of Biotechnology. 10 (13): 2446-2450.

20. Ngomuo, M., Mneney, E., Ndakidemi, P. The Effects of Auxins and Cytokinin on Growth and Development of (Musa sp.) Var. "Yangambi" Explants in Tissue Culture. (2013). American Journal of Plant Sciences. 4: 2174-2180.

21. Raghavendar G, Khannam A and Rathore TS (2019). An efficient protocol for in vitro propagation of mimosa pudica l., - a medicinally important plant species. International Journal on Agricultural Sciences. 10 (1 \& 2): 29-33.

22. Robert Lalrinsanga; H.Vanlaldiki and W.I Meitei. (2013). Department of Horticulture, College of Agriculture, Central Agricultural University, Imphal, Manipur - 795 004, INDIA.
23. Schenk, R. U. and Hildebrant, A. C. (1972). Medium and techniques for induction and growth of monocotyledonous and dicotyledonous plant cell cultures. Canadian Journal of Botany. 50: 199-200.

24. Shelake RM, Angappan K, Murugan M. (2011). An efficient protocol for large-scale plantlet production from male floral meristems of Musa spp. cultivars Virupakshi and Sirumalai. In Vitro. Cell Dev Biol Plant. 47:611-617.

25. Uzaribara, E., Nachegowda, V., Ansar, H., Sathyanarayana, B.N., Amreen T. (2015). In vitro propagation of red banana (Musa acuminata). International Quarterly Journal of Life Sciences. 10: 125-129.

26. Youmbi E, Ella B, Tomekpe K. (2006). Effect of thidiazuron on in vitro proliferation capacities of some banana (Musa spp.) cultivars with weak multiplication potential. Akdeniz Üniv Ziraat Fak Derg. 19:255-259. 